\title{
THE INFLUENCE LIFESTYLE, GROUP PREFERENCE, PERCEPTION BRAND LUXURY AND PRODUCT QUALITY TOWARD CONSUMER WILLINGNESS TO PAY ( Study of consumer iPhone at Malang )
}

\author{
Ghifari Alief Putra \\ Department of Management FEB UMM \\ E-mail: ghifarialief0910@gmail.com
}

\begin{abstract}
The purposes of this study was determine the influence of lifestyle, group preference, perception brand luxury and product quality toward consumer willingness to pay on iPhone product. The population in this study consist of society in Malang that buy iPhone product, which the value was unknown. Based on Maholtra analysis, number of sample are 85 respondent. This study use purposive sampling as the sampling technique. Data analysis was used in this study was multiple regression analysis. The result of this study shows that lifestyle, group preference influence have significant toward consumer willingness to pay partially. In addition, the results of the $F$ test describes that lifestyle, group preference, brand luxury and product quality influence on have significant consumer willingness to pay simoultaneosly
\end{abstract}

Keywords: Group Preference, Perception Brand Luxury, Perception Product Quality and Consumer Willingness to Pay

\section{PENDAHULUAN}

Industri telekomunikasi Indonesia saat ini menjadi segmen industri yang tumbuh besar dan berkembang pesat. Persaingan pada industri telekomunikasi di Indonesia saat ini menjadi sangat ketat. Dalam persaingan yang ketat ini perusahan berupaya memenangkan persaingan dengan cara menghasilkan produk yang memang sesuai dengan kebutuhan masyarakat saat ini.

Persaingan yang cukup ketat di industri telekomunikasi justru semakin memberikan keuntungan bagi masyarakat. Pasalnya dari persaingan tersebut lahir berbagai promosi dan layanan untuk masyarakat Indonesia. Masyarakat saat ini mulai berfikir secara matang dalam pengambilan keputusan pembelian terhadap handphone. Ada beberapa faktor yang akan mempengaruhi konsumen dalam pengambilan keputusan, diantaranya faktor budaya, faktor sosial, faktor pribadi, faktor psikologis. Dari faktor-faktor tersebut, nantinya konsumen akan mengambil keputusan sesuai dengan pertimbangannya.

Kebanyakan masyarakat memilih sebuah handphone atas dasar fitur - fitur handphone yang diinginkan oleh orang tersebut. Ketika sebuah produsen menawarkan fitur yang memang sesuai dengan apa yang diharapkan konsumen, maka kebanyakan konsumen bersedia untuk membayar lebih agar dapat memiliki handphone yang dikeluarkan oleh produsen tersebut.

Kesediaan untuk membayar (willingness to pay) dapat diartikan 
sebagai kesediaan masyarakat untuk menerima beban pembayaran, sesuai dengan besarnya jumlah yang telah ditetapkan seringkali dipengaruhi oleh gaya hidup (lifestyle) seseorang. Secara sadar atau tidak lifestyle berkaitan erat dengan WTP , karena lifestyle seseorang mencerminkan kepribadian seseorang yang terlihat dari aktifitas , opini serta minat orang tersebut.

Gaya hidup mencakup sekumpulan kebiasaan, pandangpandangan dan pola-pola respons terhadap hidup serta terutama perlengkapan untuk hidup (Adlin, 2006). Cara berpakaian, cara kerja, pola konsumsi, bagaimana individu mengisi kesahariannya merupakan unsur-unsur yang membentuk gaya hidup. Gaya hidup dipengaruhi oleh keterlibatan seseorang dalam kelompok social atau kelompok referensi mereka dari seringinya berinteraksi dan menanggapi berbagai stimulus disana.

Peran kelompok referensi sangat berpengaruh terhadap pemberian saran suatu keputusan pembelian. Setiap hari masyarakat akan lebih sering beretemu dengan waktu pertemuan yang sering, maka masyarakat juga membuat teman mereka sebagai pembanding atau referensi dalam melakukan keputusan pembelian. Presepsi kelompok referensi yang terdiri dari kalangan menengah keatas seringkali mengutamakan merek/brand. Brand yang mereka pilih untuk pembelian suatu produk adalah brand yang memang merupakan tergolong mewah/luxury di kelasnya.

Brand Luxury atau merek mewah adalah sebuah merek yang sangat baik, memiliki harga tinggi dan sesuai, setidaknya bagi kalangan elite sosial ekonomi. Pengertian dari brand luxury ini relatif, karena ada kalangan orang yang memang membeli suatu produk tersebut dikarenakan presepsi mereka terhadap merek tersebut terkesan mewah atau ada juga kalangan orang yang berpresepsi bahwa setiap produk yang berlabel brand luxury selalu memiliki kualitas produk yang baik dibandingkan dengan merek - merek lainnya.

Product Quality yang baik akan memberikan gambaran sejauh mana upaya perusahaan untuk menciptakan kepuasan konsumen atas produk yang ditawarkan. Product quality menjadi tolak ukur atas keberhasilan perusahaan untuk mendukung agar produk tetap diminati dan tetap menjadi pilihan konsumen dan merek menjadi salah satu penentu upaya perusahaan dalam mempengaruhi keputusan yang akan ditetapkan oleh konsumen. Merek ini mampu memberikan pedoman, jaminan, kekuatan, keyakinan, dan harapan kepada pelanggan bahwa ia akan terpuaskan.

\section{TINJAUAN PUSTAKA}

Consumer Willingness To Pay merupakan kesediaan konsumen untuk membayar atau willingness to pay meruapakan keadaan dimana seorang konsumen bersedia mengeluarkan sejumlah uang untuk mendapatkan barang yang dia inginkan. Secara umum, willingness to pay (WTP) atau kemauan atau keinginan untuk membayar didefinisikan sebagai jumlah yang dapat dibayarkan seorang konsumen untuk memperoleh suatu barang atau jasa. Zhao dan Kling (2005) 
menyatakan bahwa WTP adalah harga maksimum dari suatu barang yang ingin dibeli oleh konsumen pada waktu tertentu.

Consumer Willingness To Pay (WTP) kesediaan konsumen untuk membayar harga yang lebih tinggi untuk suatu merek dari merek lainnya yang mereka anggap cukup sebanding. Indikator pada WTP disini, yaitu : Konsumen bersedia membayar lebih untuk produk iPhone dibanding produk lain, konsumen tetap memilih membeli iPhone meskipun produk lain lebih murah dibanding iPhone.

Lifestyle, merupakan pola hidup yang menggambarkan aktivitas, minat, dan opini individu yang berinteraksi dengan lingkungan sekitarnya. Widjaja (2007) mengutarakan bahwa konsumen termotivasi dalam berbelanja karena unsur dan dorongan kebutuhan yang muncul karena lifestyle. Terdapat empat kategori yang menjadi motif dalam proses pembelian oleh konsumen guna memenuhi kebutuhan dan keinginan konsumen itu sendiri sehingga tercipta kepuasan terhadap apa yang telah konsumen dapatkan karena lifestyle menurut Widjaja (2007) yaitu utilitarian purchases, indulgences, lifestyle luxuries serta aspirational luxuries.

Lifestyle merupakan pola hidup yang menggambarkan aktivitas, minat, dan opini individu yang berinteraksi dengan lingkungan sekitarnya, lifestyle juga mempengaruhi keputusan pembelian seseorang terhadap produk iPhone. Maka dari itu indikatornya adalah sebagai berikut : iPhone memainkan peranan penting dalam aktivitas sehari - hari, iPhone membantu dalam berinteraksi dengan orang lain, iPhone lebih sering digunakan daripada media lainnya untuk mencari informasi, iPhone diminati oleh berbagai kalangan masyarakat.

Reference Group atau kelompok referensi merupakan suatu kelompok yang ikut berpengaruh dalam pengambilan keputusan seseorang dalam pembelian, dimana kelompok ini biasanya memiliki tingkah laku yang serupa dalam melakukan pembelian produk. Dharmmesta dan Handoko (2008) menjelaskan bahwa reference group adalah kelompok sosial yang menjadi ukuran seseorang untuk membentuk kepribadian dan perilakunya.

Interaksi mereka sering dilakukan secara individual (face to face) sehingga seseorang akan lebih terpengaruh oleh orang lain untuk membeli sesuatu, biasanya masing-

masing kelompok mempunyai opinion leader yang dapat

mempengaruhi anggotanya. Indikator dari reference group adalah sebagai berikut : Saran dari kerabat tentang iPhone, rekomendasi dari teman sebaya, kelompok pergaulan mereka menggunakan iPhone.

Perception Brand Luxury yaitu merek sangat bernilai karena mampu mempengaruhi pilihan konsumen. Menurut Djan dan Ruvendi (2006) merek adalah nama, istilah, tanda, simbol, rancangan atau kombinasi dari hal-hal tersebut yang bertujuan untuk mengidentifikasikan produk atau jasa dari satu atau kelompok penjual dan membedakannya dari produk atau jasa pesaing.

Dalam pengertian merek ada juga yang mengklasifikasikan merek, seperti brand luxury/merek mewah. 
Brand luxury ini biasanya diminati oleh kalangan masyarakat kelas atas. Banyak pihak yang berusaha menguraikan konsep luxury, namun pada kenyataannya tetap saja kita hanya bisa mengerti tanpa tahu persis arti secara universal, hal ini dikarenakan konsep luxury merupakan sesuatu yang tidak mudah untuk didefinisikan mengingat konsep ini terus berkembang dan bersifat subjektif. Seringkali luxury digunakan untuk menggambarkan sesuatu hal yang tidak terlalu penting namun diinginkan atau sebuah tingkat yang mampu memberikan rasa nyaman dan kegemaran yang berlebih. (Debnam dan Svinos, 2006).

Brand Luxury merupakan merek mewah dalam presepsi konsumen iPhone itu sendiri. Merek mewah ini dengan sendirinya akan menggambarkan suatu prestise bagi penggunanya. Dalam penelitian ini yang menjadi indikator pada brand luxury, yaitu : iPhone merupakan simbol prestise, iPhone merupakan simbol dari sebuah kemewehan, iPhone akan meningkatkan status sosial.

Kualitas produk adalah "the ability of a product to perform its functions, it includes the product's overall durability, reliability, precision, ease of operation and repair, and other valued attributes"(Kotler and Armstrong, 2012) yang artinya kemampuan sebuah produk dalam memperagakan fungsinya, hal itu termasuk keseluruhan durabilitas, reliabilitas, ketepatan, kemudahan pengoperasian dan reparasi produk juga atribut produk lainnya.

Menurut Agus Ahyari (2008) Kualitas diartikan sejumlah dari artribut atau sifat-sifat sebagaimana dideskripsikan dalam produk yang bersangkutan. Konsumen sebagai pengguna produk adalah sebagai penentu atau yang membuat keputusan akhir terhadap mutu produk meskipun produsen memutuskan tujuan untuk apa hasil atau produk tersebut dimaksudkan.

Product Quality merupakan keseluruhan kualitas produk atau keunggulan suatu produk/jasa layanan yang berkaitan dengan maksud yang diharapkan. Indikator dari kualitas produk dalam penelitian ini adalah produk iPhone, yang mencakup : tampilan iPhone menarik, iPhone menawarkan aplikasi yang canggih, iPhone menyajikan desain yang elegant, iPhone menggunakan cassing dari bahan yang berkualitas, iPhone menawarkan gudang media seperti musik ataupun film yang lengkap.

Berdasarkan pengembangan dan kajian dari beberapa literatur dan hasil penelitian terdahulu, maka berikut ini adalah kerangka penelitian yang ditunjukan pada gambar 1 .

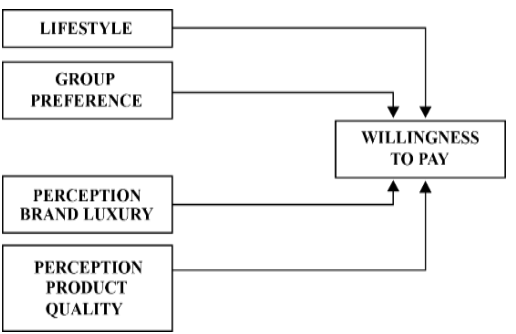

Gambar 1. Kerangka Penelitian H1: Lifestyle, Group Preference, Perception Brand Luxury serta Product Quality memliki pengaruh secara parsial terhadap Consumer Willingness To Pay.

\section{METODE PENELITIAN}

Lokasi penelitian ini dilakukan di Kota Malang, tepatnya outlet resmi 
apple di kota Malang yang beralamat di Jalan Brigjend Selamat Riyadi No. 10 Malang, Jawa Timur. Adapun pertimbangan pemilihan lokasi penelitian yaitu Kota Malang dikarenakan Malang merupakan kota terbesar kedua di Jawa Timur.

Jenis penelitian ini adalah penelitian kuantitatif deskriptif dengan teknik survei. Penelitian Survei adalah metode penelitian kuantitatif yang digunakan untuk mendapatkan data yang terjadi pada masa lampau atau saat ini, tentang keyakinan pendapat karakteristik perilaku hubungan variabel dan untuk menguji beberapa hipotesis tentang variabel sosiologis dan psikologis dari sampel yang diambil dari populasi tertentu, teknik pengumpulan data dengan pengamatan (wawancara atau kuisioner)yang tidak mendalam dan hasil penelitian cenderung untuk digeneralisasikan (Sugiyono, 2013).

Lifestyle merupakan pola hidup yang menggambarkan aktivitas, minat, dan opini individu yang berinteraksi dengan lingkungan sekitarnya, lifestyle juga mempengaruhi keputusan pembelian seseorang terhadap produk iPhone. Maka dari itu indikatornya adalah sebagai berikut : iPhone memainkan peranan penting dalam aktivitas sehari - hari, iPhone membantu dalam berinteraksi dengan orang lain, iPhone lebih sering digunakan daripada media lainnya untuk mencari informasi, iPhone diminati oleh berbagai kalangan masyarakat.

Reference Group adalah kelompok sosial yang menjadi ukuran seseorang untuk membentuk kepribadian dan perilakunya. Interaksi mereka sering dilakukan secara individual (face to face) sehingga seseorang akan lebih terpengaruh oleh orang lain untuk membeli sesuatu, biasanya masingmasing kelompok mempunyai opinion leader yang dapat mempengaruhi anggotanya. Indikator dari reference group adalah sebagai berikut : saran dari kerabat tentang iPhone, rekomendasi dari teman sebaya, kelompok pergaulan menggunakan iPhone.

Brand Luxury merupakan merek mewah dalam presepsi konsumen iPhone itu sendiri. Merek mewah ini dengan sendirinya akan menggambarkan suatu prestise bagi penggunanya. Dalam penelitian ini yang menjadi indikator pada brand luxury, yaitu : iPhone merupakan simbol prestise, iPhone merupakan simbol dari sebuah kemewehan iPhone akan meningkatkan status sosial.

Product Quality merupakan keseluruhan kualitas produk atau keunggulan suatu produk/jasa layanan yang berkaitan dengan maksud yang diharapkan. Indikator dari kualitas produk dalam penelitian ini adalah produk iPhone, yang mencakup : tampilan iPhone menarik, iPhone menawarkan aplikasi yang canggih, iPhone menyajikan desain yang elegant, iPhone menggunakan cassing dari bahan yang berkualitas, iPhone menawarkan gudang media seperti musik ataupun film yang lengkap.

Consumer Willingness To Pay (WTP) kesediaan konsumen untuk membayar harga yang lebih tinggi untuk suatu merek dari merek lainnya yang mereka anggap cukup sebanding. Indikator pada WTP disini, yaitu : konsumen bersedia 
membayar lebih untuk produk iPhone dibanding produk lain, konsumen tetap memilih membeli iPhone meskipun produk lain lebih murah dibanding iPhone.

Teknik analisis yang digunakan dalam penelitian ini adalah teknik analisis regresi berganda. Regresi berganda seringkali digunakan untuk mengatasi permasalahan analisis regresi yang melibatkan hubungan dari dua atau lebih variabel bebas (Sujianto, 2007). Dalam penelitian ini, variabel independen yang digunakan adalah consumer willingness to pay. Oleh karena itu, model persamaan regresi yang digunakan untuk menguji hipotesis ini adalah :

$\boldsymbol{Y}=\boldsymbol{\beta}_{1} \boldsymbol{X}_{1}+\boldsymbol{\beta}_{2} \boldsymbol{X}_{2}+\boldsymbol{\beta}_{3} \boldsymbol{X}_{3}+\boldsymbol{\beta}_{4} \boldsymbol{X}_{4}+\boldsymbol{e}$

Keterangan:

$\mathrm{Y}=$ consumer willingness to pay, $\beta_{1 \ldots} \beta_{3}=$ Koefisien regresi, $X_{1}=$ Lifetyle, $\mathrm{X}_{2}=$ Group Preference, $\mathrm{X}_{3}=$ Brand Luxury, $\mathrm{X}_{4}=$ Product Quality, $\mathrm{e}=$ Erorr

\section{HASIL PENELITIAN DAN PEMBAHASAN}

Hasil uji instrumen, seluruh indikator dalam variabel penelitian ini mempunyai nilai $r$ hitung dengan menggunakan Corrected Item Total

Correlation lebih besar dari nilai $r$ tabel yaitu 0,1803 , maka dapat membuktikan bahwa butir pernyataan yang digunakan sebagai dalam kuisioner penelitian ini valid dan tepat digunakan untuk mengukur jawaban responden.

Uji reliabilitas semua variabel dalam penelitian ini mempunyai koefisien alpha (a) $>0,60$. Sehingga dapat memberikan jaminan tingkat konsistensi jawaban responden dan kuisioner dalam penelitian ini layak disebarkan kepada responden untuk dapat dijadikan sebagai instrumen dalam penelitian ini.

Berdasarkan hasil uji normalitas dengan menggunakan Kolmogrof Smirnov Test diperoleh hasil bahwa nilai signifikansi sebesar 0,427 lebih besar dari 0,05 . Sehingga dapat disimpulkan bahwa data berdistribusi normal. Hasil uji multikolinearitas dalam penelitian ini dapat dilihat dari nilai Tolerance kedua variabel bebas lebih besar dari 0,10 dan VIF kurang dari 10. Maka dapat disimpulkan tidak terjadi multikolinearitas dan model regresi dalam penelitian ini dikatakan baik.

Uji Heteroskedastisitas dalam penelitian ini menggunakan

pengujian Sperman's rho. Nilai variabel dengan understandardized residual memiliki nilai signifikansi lebih dari 0,05 . Karena signifikansi lebih dari 0,05 maka dapat disimpulkan tidak terjadi masalah heteroskedastisitas dan model regresi dalam penelitiam ini dikatakan baik.

Hasil Analisis Agresi Linear Berganda

Tabel 1. Hasil Analisis Linear Berganda

\begin{tabular}{lc}
\hline Lifestyle $\left(\mathrm{X}_{1}\right)$ & 0,232 \\
Group Preference & 0,495 \\
$\mathrm{X}_{2}$ & 0,020 \\
Brand Luxury $\left(\mathrm{X}_{3}\right)$ & 0,056 \\
Product Quality & \\
$\left(\mathrm{X}_{4}\right)$ & \\
\hline \multicolumn{1}{c}{ Berdasarkan Tabel 1 dapat }
\end{tabular}
ditulis dalam bentuk persamaan regresi bentuk Standardized Coefficients diperoleh persamaan sebagai berikut: 
$\mathrm{Y}=0,232 \mathrm{X} 1+0,495 \mathrm{X} 2+0,020 \mathrm{X} 3$ $+0,056 \mathrm{X} 4$

Dari persamaan garis regresi linier berganda, maka dapat diartikan bahwa: $b 1=0,232$ merupakan slope atau koefisien arah variabel Lifestyle (X1) yang mempengaruhi consumer willingness to pay, artinya variabel Brand luxury berpengaruh positif terhadap consumer willingness to pay (Y). Hal ini menunjukan bahwa lifestyle (X1) memiliki pengaruh terhadap consumer willingness to pay (Y). b2=0,495 merupakan slope atau koefisien arah variabel Group Preference (X2) yang mempengaruhi consumer willingness to pay (Y), artinya variabel Group Preference berpengaruh positif terhadap consumer willingness to pay, jika variabel lainnya dianggap

konstan. $\mathrm{b} 3=0,020$ merupakan slope atau koefisien arah variabel Brand Luxury (X3) yang mempengaruhi consumer willingness to pay (Y), artinya variabel kualitas produk berpengaruh positif terhadap consumer willingness to pay. b4 = 0,056 merupakan slope atau koefisien arah variabel product quality (X4) yang mempengaruhi consumer willingness to pay (Y), artinya variabel kualitas produk berpengaruh positif terhadap consumer willingness to pay.

Tabel 2. Hasil Uji t

\begin{tabular}{lc}
\hline Lifestyle $\left(\mathrm{X}_{1}\right)$ & 2,395 \\
Group Preference & 5,111 \\
$\left(\mathrm{X}_{2}\right)$ & 0,238 \\
Brand Luxury $\left(\mathrm{X}_{3}\right)$ & 0,627 \\
Product Quality \\
$\left(\mathrm{X}_{4}\right)$ \\
\hline \multicolumn{2}{c}{ Variabel lifestyle memiliki t } \\
hitung sebesar 2,395 dengan nilai \\
signifikasi 0,019 yang berarti thitung
\end{tabular}

$\mathrm{t}_{\text {tabel }}(2,395>1,990)$ yang artinya variabel lifestyle $\left(\mathrm{X}_{1}\right)$ secara parsial memiliki pengaruh yang signifikan terhadap consumer willingness to pay (Y).

Variabel Group Preference memiliki thitung sebesar 5,111 dengan nilai signifikasi 0,000 yang berarti $\mathrm{t}_{\text {hitung }}>\mathrm{t}_{\text {tabel }}(5,111>1,990)$ yang artinya variabel Group Preference $\left(\mathrm{X}_{2}\right)$ secara parsial memiliki pengaruh yang signifikan terhadap consumer willingness to pay $(\mathrm{Y})$.

Variabel perception Brand Luxury memiliki thitung sebesar 0,238 dengan nilai signifikasi 0,813 yang berarti $t_{\text {hitung }}<\mathrm{t}_{\text {tabel }}(0,238<1,990)$ yang artinya variabel Brand Luxury secara parsial tidak memiliki pengaruh yang signifikan terhadap consumer willingness to pay.

Variabel Perception Product Quality memiliki thitung sebesar 0,627 dengan niali signifikasi 0,533 yang berarti $t_{\text {hitung }}<\mathrm{t}_{\text {tabel }}(0,627<1,990)$ yang artinya variabel Product Quality secara parsial tidak memiliki pengaruh yang signifikan terhadap consumer willingness to pay.

Berdasarkan hasil tersebut dapat diketahui bahwa lifestyle, group preference, brand luxury, serta product quality memiliki pengaruh secara simultan terhadap consumer willingness to pay, serta hanya variabel lifestyle dan group preference yang memiliki pengaruh parsial terhadap consumer willingness to pay.

\section{SIMPULAN}

dan pembahasan maka dapat disimpulkan sebagai bahwa pendapat konsumen mengenai lifestyle produk iPhone adalah sangat tinggi, group 
preference berada pada kategori sangat tinggi, perception brand luxury berada pada kategori cukup tinggi serta perception product quality berada pada kategori sangat baik di benak konsumen. Kesimpulan kedua yaitu terdapat pengaruh antara lifestyle, group preference, perception brand luxury, serta product quality terhadap consumer willingness to pay pada iPhone secara simultan terhadap consumer willingness to pay. Terakhir, adanya pengaruh antara lifestyle serta group preference secara parsial terhadap consumer willingness to pay pada iPhone.

\section{DAFTAR PUSTAKA}

Adlin, Alfathri , 2006. Resistensi Gaya Hidup : Teori dan Realitas. Yogyakarta : Jalasutra.

Ahyari, Agus, 2008, Anggaran Perusahaan, Buku I, BPFE, Yogyakarta.

Anggara , Febri , 2014 , Pengaruh Gaya Hidup Dan Kelompok Refernsi Terhadap Keputusan Pembelian, Malang

Buchari Alma. 2005. Management Pemasaran dan Pemasaran Jasa. Alfabeta: Bandung

Debnam, N., \& Svinos, G (2006). Luxury Brands in China. KPMG

Dharmmesta, B., \& Handoko, H. (2008). Manajemen Pemasaran

Djan, I., \& Ruvendi, R. (2006). Prediksi Perpindahan Penggunaan Merek Handphone Dikalangan Mahasiswa. Jurnal Ilmiah Binaniaga, 2(1).

Hawkins,Del I., Mothersbaugh, David L. 2010. Consumer Behavior: Building Marketing
Strategy. New York : McGrawHills.

Indriantoro, Supomo, 2006, Metodologi Penelitian Bisnis, Edisi Pertama, Penerbit: Liberty, Yogyakarta.

Kotler, Philip and Garry Amstrong. 2012. Principles of Marketing. New Jersey: Pearson Education Limited

Kotler, Philip, 2007, Manajemen Pemasaran, Analisis Perencanaan, Pengendalian, Prentice Hall, Edisi Bahasa Indonesia, Salemba Empat, Jakarta.

Kotler, Amstrong, 2008, PrinsipPrinsip Pemasaran 1, Edisi keduabelas, Erlangga, Jakarta

Latumahina , Grace , 2014 , Kesediaan Membayar pada Green Residential, Surabaya

Malhotra, N.K. (2010). Marketing Research. An applied orientation. New Jersey : Pearson Education

Mullin, John W, Orville C Walker. 2005. Marketing Management A Strategic Decision, fifth edition, New York: McGraw Hill.

Ria Dwi , 2015 , Pengaruh Brand Luxury, Brand Awareness Dan Product Quality Terhadap Consumer Willingness To Pay ,Malang

Rizky, A., \& Pantawis, S. (2011). Pengaruh Citra Dan Sikap Merek Terhadap Ekuitas Merek. Vol.7, No.2, 181-196.

Schiffman, L., \& Kanuk, L. (2008). Perilaku Konsumen. Jakarta : Indeks. 
Selfia Ladiyance, 2014, Variabel Variabel Yang Mempengaruhi Kesediaan Membayar

( Willingness To Pay ) Masyarakat Bidaracina Jatinegara Jakarta Timur, Jakarta

Solomon, M.R. (2011), Consumen Behaviour, New Jersey: Prentice Hall

Sugiyono, 2013, Metode Penelitian Manajemen, Yogyakarta , Alfabeta

Sugiyono, 2015, Statistika untuk Penelitian, Yogyakarta, Alfabeta
Tjiptono, F. 2008. Strategi Pemasaran. Yogyakarta: CV Andi Offset

Whitehead, J.C., 2005, Combining Willingness to Pay and Behavior Data With Limited Information, Resource and Energy Economics, Vol. 27, 143- 155.

Widjaja, M., Wijaya, S., dan Jokom, R., 2007., Analisis Penilaian Konsumen Terhadap Ekuitas Merek Coffee Shops di Surabaya. Jurnal Manajemen Perhotelan, Vol. 3 No. 2, 89 101 